\title{
PENGARUH PENGELUARAN PEMERINTAH, TENAGA KERJA SERTA PENANAMAN MODAL DALAM NEGERI TERHADAP PERTUMBUHAN EKONOMI INDONESIA
}

\author{
Suherman ${ }^{1}$ \\ Universitas Muhammadiyah Jambi ${ }^{1}$ \\ suhermanrika17@gmail.com. \\ Rika Neldawati ${ }^{2}$ \\ Universitas Muhammadiyah Jambi ${ }^{2}$ \\ rikaneldawaty1079@,gmail.com \\ Adi Putra ${ }^{3}$ \\ Universitas Muhammadiyah Jambi ${ }^{3}$ \\ putramm@,yahoo.co.id
}

\begin{abstract}
ABSTRAK
Pembangunan secara berkelanjutan betujuan untuk mengatasi masalah kemiskinan, pengangguran serta mendorong kesejahteraan masyarakat. Kondisi pererkonomian Indonesia yang berusaha pulih dari krisis ekonomi dengan pertumbuhan rata-rata sebesar 4,5\% per tahun perlu ditingkatkan lagi sehingga dapat menciptakan stabilitas perekonomian dan pembangunan yang berkelanjutan. Untuk itu perlu diketahui faktor-faktor apa saja yang mempengaruhi pertumbuhan ekonomi di Indonesia. Metode yang dipergunakan pada penelitian ini yaitu explanatory Research, dimana sumber data penelitian dari BPS Republik Indonesia yang meliputi data pertumbuhan ekonomi (PE) sebagai dependent variabel /(Y) serta Pengeluaran Pemerintah (PP), Angkatan Kerja (AK) dan Penanaman Modal Dalam Negeri $(P M D N)$ sebagai independent variabel $\left(X_{1}, X_{2}, X_{3}\right)$. Selanjutnya data tersebut dianalisis secara kuantitatif menggunakan multiple linear regression untuk mengetahui pengaruh antara variabel-variabel tersebut sehingga akan diperoleh kejelasan fenomena yang terjadi di tataran empiris serta didapatkan jawaban (verificative) melalui pengujian hipotesis.

Hasil analisis data pada penelitian periode tahun 2000-2019 didapatkan perkembangan secara rata-rata PE 5,3\%, PP 0,86\%, AK 1,82\% dan PMDN 15,22\% pertahun. Hasil analisis regresi didapatkan pengaruh parsial $X$ terhadap $Y$ yaitu $X_{1}(1,427), X_{2}(0,52), X_{3}(2,140)$. Sedangkan hasil pengujian hipotesis secara simultan didapkan variabel Independent $X, X_{2}, X_{3}$ berpengaruh signifikan terhadap Y. Sedangkan hasil analisis secara parsial PP dan PMDN berpengaruh signifikan terhadap pertumbuhan ekonomi Indonesia, sedangkan TK tidak berpengaruh signifikan terhadap pertumbuhan ekonomi.
\end{abstract}

Kata kunci : kemiskinan, pengangguran, kesejahteraan, masyarakat, PMDN.

\section{PENDAHULUAN}

Pertumbuhan ekonomi merupakan proses perubahan kondisi perekonomian suatu negara secara berkesinambungan menuju keadaan yang lebih baik selama periode tertentu. Suatu perekonomian dikatakan mengalami suatu perubahan akan perkembangannya apabila tingkat kegiatan ekonomi lebih tinggi dari pada yang dicapai pada masa sebelumnya. Keberhasilan pembangunan suatu daerah dapat dilihat dari tingkat pertumbuhan ekonominya. Oleh sebab itu, setiap daerah selalu menetapkan target tingkat pertumbuhan ekonomi yang tinggi didalam 
perencanaan dan tujuan pembangunan daerahnya. Pertumbuhan ekonomi yang tinggi dan berkelanjutan merupakan kondisi utama bagi kelangsungan pembangunan ekonomi.

Pertumbuhan ekonomi merupakan kunci dari tujuan ekonomi makro, hal ini didasari tiga alasan antara lain: Pertama, penduduk selalu bertambah. Kedua, selama keinginan dan kebutuhan selalu tidak terbatas, perekonomian harus selalu mampu memproduksi lebih banyak barang dan jasa untuk memenuhi keinginan dan kebutuhan tersebut. Ketiga, usaha menciptakan kemerataan ekonomi (economic stability) melalui retribusi pendapatan (income redistribution) akan lebih mudah dicapai dalam periode pertumbuhan ekonomi yang tinggi. Sedangkan Indikator penting untuk mengetahui kondisi ekonomi di suatu negara dalam suatu periode tertentu ditunjukkan oleh data Produk Domestik Bruto (PDB). Menurut Badan Pusat Statistik, Pruduct Domestic Bruto merupakan jumlah nilai tambah yang dihasilkan oleh seluruh unit usaha dalam suatu negara tertentu, atau merupakan jumlah nilai barang dan jasa akhir yang dihasilkan oleh seluruh unit ekonomi. Perekonomian suatu negara dikatakan mengalami pertumbuhan jika jumlah balas jasa riil terhadap penggunakan faktor-faktor produksi pada tahun tertentu lebih besar dari pada tahun-tahun sebelumnya (Haryanto, 2013).

Pertumbuhan ekonomi sendiri merupakan konsep yang menjelaskan mengenai faktorfaktor yang menentukan kenaikan output dalam jangka panjang serta penjelasan mengenai bagaimana faktor-faktor tersebut berinteraksi satu sama lain. Output yang digunakan dalam pengukuran pertumbuhan ekonomi di wilayah dipengaruhi oleh banyak faktor baik dari dalam maupun dari luar wilayah itu sendiri antara lain seperti pengeluaran pemerintah, human capital investment, angkatan kerja dan penanaman modal dalam negeri dan luar negeri/asing.

Todaro, 2013 menjelaskan dimana pembangunan ekonomi secara berkelanjutan sangat diharapkan oleh dunia usaha dan masyarakat, karena pertumbuhan yang membaik akan dapat mengatasi masalah kemiskinan, pengangguran, dan kesejahteraan masyarakat. Dengan kata lain negara yang mengalami pertumbuhan ekonomi yang tinggi, akan turut mendongkrak pendapatan nasional sehingga alokasi untuk pembiayaan dan pembangunan infrastruktur akan meningkat, akses pasar terbuka, investasi meningkat dan kesejahteraan penduduknya juga akan meningkat.

Perekonomian nasional periode 2000-an yang cenderung berfluktuasi dengan pertumbuhan sebesar $4,5 \%$ per tahun masih menggambarkan kondisi pererkonomian Indonesia yang masih belum membaik pasca dilanda krisis ekonomi yang terjadi di era 1990-an. Untuk itu pemerintah perlu mendorong peningkatan pertumbuhan ekonomi yang baik dan 
berkelanjutan serta menjaga stabilitas sektor rill melalui penetapan kebijakan fiskal dan kebijakan moneter yang tepat khususnya dalam perencanaan pengeluaran pemerintah. Sehingga kebijakan tersebut akan mampu menciptakan stabilitas dalam ekonomi nasional serta mendorong pertumbuhan ekonomi. Selain pengeluaran pemerintah tersebut penting juga diketahui pengaruh dari, tenaga kerja dan dana investasi PMA dan PMDN terhadap pertumbuhan ekonomi di Indonesia, karena hubungan antar variabel tersebut sangat penting

Berdasarkan uraian diatas maka penelitian ini bertujuan menganalisis kondisi pertumbuhan ekonomi, pengeluaran pemerintah, angkatan kerja dan penanaman modal dalam negeri serta melihat pengaruh pengeluaran pemerintah, angkatan kerja, dan penanaman modal dalam negeri terhadap pertumbuhan ekonomi di Indonesia selama periode tahun 2000-2019.

\section{METODOLOGI}

Jenis Penelitian ini adalah penelitian ini merupakan penelitian yang menjelaskan explanatory research. Cooper, 2008 menjelaskan metode penelitian explanatory dilakukan untuk memperoleh kejelasan fenomena yang terjadi di tataran empiris (real world) dan berusaha untuk mendapatkan jawaban (verificative). Penelitian explanatory merupakan penelitian yang menjelaskan gejala yang ditimbulkan oleh suatu objek penelitian yang bertujuan untuk menjelaskan hubungan kausalitas antara variabel-variabel melalui pengujian hipotesis.

Data yang dipergunakan dalam penelitian ini adalah data kuantitatif yang bersumber dari data sekunder. Algifari (2010) mengemukakan data sekunder adalahdata yang tidak langsung memberikan data kepada peneliti, misalnya penelitian harus melalui terbitan/laporan suatu lembaga. Jenis data yang dikumpulkan pada penelitian ini meliputi data sekunder yaitu: Data pertumbuhan ekonomi Indonesia, pengeluaran pemerintah, angkatan kerja serta data PMDN di Indonesia Periode 2000-2019

Data yang didapatkan di analisis secara deskriptif kualitatif maupun kuantitatif, dimana analisis kualitatif bertujuan untuk mengetahui perkembangan pertumbuhan ekonomi, pengeluaran pemerintah, angkatan kerja dan penanaman modal dalam negeri (PMDN) di Indonesia. Selanjutnya analisis kuantitatif menggunakan analisis regresi linear berganda untuk mengetahui pengaruh antara variabel independen berupa pengeluaran pemerintah, angkatan kerja danPMDN terhadap terhadap pertumbuhan ekonomi Indonesia sebagaivariabel dependen.

Rumus umum dari regresi linear berganda berupa $Y=a+\beta_{1} X_{1}+\beta_{2} X_{2}+\beta_{3} X_{3}+e$. selanjutnya diturunkan kembali menjadi persamaan menjadi $Y=\alpha+\beta_{1} \log X_{1}+\beta_{2} \log X_{2}+$ 


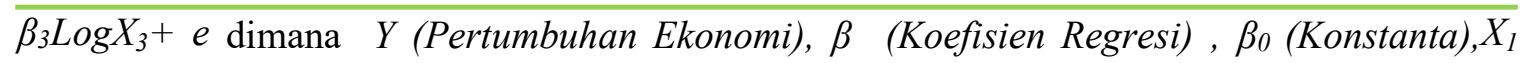
(Pengeluaran Pemerintah), $X_{2}$ (Angkatan Kerja yang Bekerja) dan $X_{3}$ (Penanaman Modal Dalam Negeri)

Tahapan analisis terakhir adalah pengujian hipotesis pada penelitian ini melalui analisis Koefisien Determinasi yang menyatakan proporsi variasi keseluruhan dalam nilai dependen yang dapat diterangkan atau diakibatkan oleh hubungan linear dengan variabel independen, selain itu (sisanya) diterangkan oleh variabel yang lain (galat atau peubah lainnya). Uji F untuk menguji pengaruh variabel bebas secara bersama sama terhadap variabel tergantung dan Uji $t$ untuk menguji pengaruh variabel bebas secara parsial terhadap variabel tergantung (Priyatno, 2013). Terhadap rumusan hipotesis tersebut, selanjutnya dilakukan pengujian hipotesis yaitu tentang diterima atau ditolaknya suatu hipotesis. Untuk melakukan pengujian digunakan statistik uji-t dua arah (two tail) signifikan sebesar 10\%

\section{HASIL}

Berdasarkan hasil penelitian didapati kondisi pertumbuhan Ekonomi Indonesia pada periode tahun 2000 hingga tahun 2004 mulai membaik setelah dilanda krisis moneter yang terjadi di Indonesia pada tahun 1997 dengan rata-rata pertumbuhan sebesar 4,5\% per tahun. Grafik dibawah ini berikutnya menggambarkan pertumbuhan ekonomi Indonesia periode tahun 2000-2019.

\section{Grafik. 1}

\section{Pertumbuhan ekonomi Indonesia periode tahun 2000-2019.}

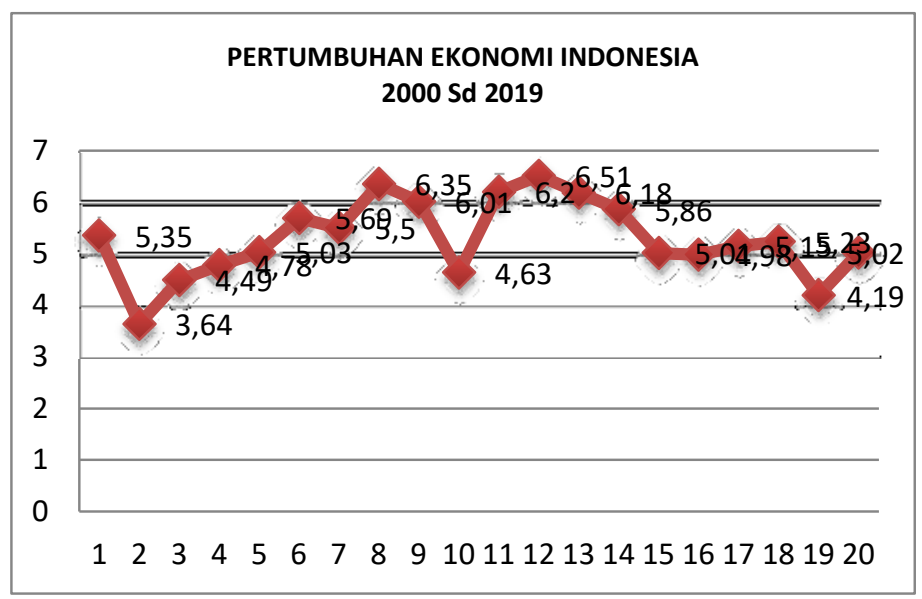

Pada Grafik. 1 terlihat dimana secara rata-rata pertumbuhan ekonomi Indonesia pada periode tahun 2000-2019 mencapai 5,31 persen pertahunnya. Pengeluaran pemerintah Indonesia pada periode tahun 2000-2019 cenderung mengalami kenaikan dengan kondisi 
tertinggi terjadi dari tahun 2000 ke tahun 2001 sebesar 99,55 persen dengan perkembangan pengeluaran terendah terjadi pada periode tahun 2015 yaitu sebesar 6,06 persen. Secara ratarata perkembangan pengeluaran pemerintah di Indonesia dari tahun 2000-2019 yaitu sebesar 20,86 persen. Jumah angkatan kerja pada periode yang sama juga mengalami peningkatan pertahunnya. Perkembangan tenaga kerja di Indonesia yang tertinggi terjadi pada tahun 2012 yaitu sebesar 4,73 persen.

\section{Grafik. 2}

Perkembangan tenaga kerja Indonesia periode tahun 2000-2019

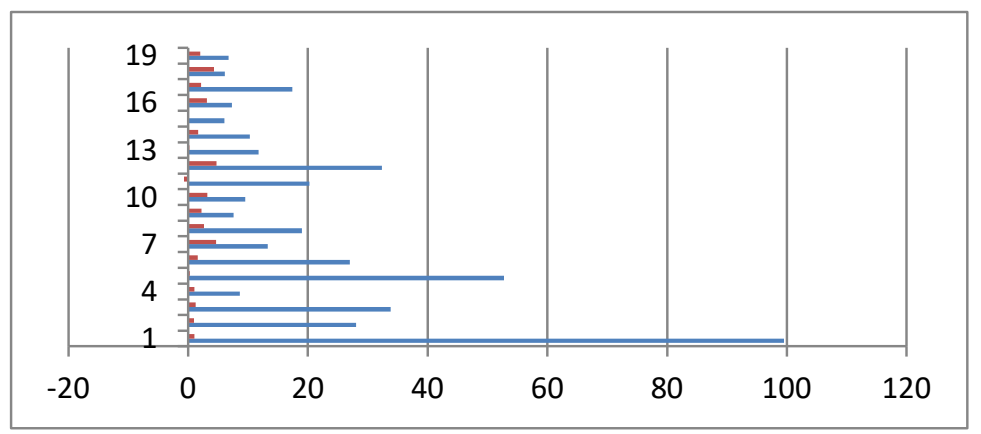

Pada Grafik. 2 diatas terlihat dimana perkembangan tenaga kerja Indonesia periode tahun 2000-2019 dimana peningkatan kesempatan kerja yang meningkat ternyata diiringi dengan peningkatan angkatan kerja yang mencari pekerjaan oleh karena itu, pembangunan aspek ketenagakerjaan harus terus dilakukan. Pada tahun 2011 tenaga kerja mengalami penurunan dari tahun sebelumnya yaitu sebesar $-0,73$ persen hal ini terjadi karena perkembangan angkatan kerja dipengaruhi oleh pertumbuhan penduduk secara alami karena semakin banyaknya penduduk dari daerah yang masuk ke Kota. Rata-rata perkembangan tenaga kerja di Indonesia dari tahun 2000-2019 adalah sebesar 1,82 persen pertahunnya.

Perkembangan Penanaman Modal Dalam Negeri di Indonesia periode 2000-2019 mengalami fluktuasi, dimana peningkatan terbesar terjadi tahun 2003 sebesar 91,58 persen atau dari Rp. 25.307,6 miliar rupiah pada tahun 2002 meningkat menjadi Rp 48.484,8 miliar rupiah pada tahun 2003. Sedangkanperkembangan PMDN di Indonesia yang paling rendah yaitu pada tahun 2001 ke 2002 yaitu sebesar $-56,97$ persen. 


\section{Grafik. 3}

Perkembangan PMDN di Indonesia periode tahun 2000-2019

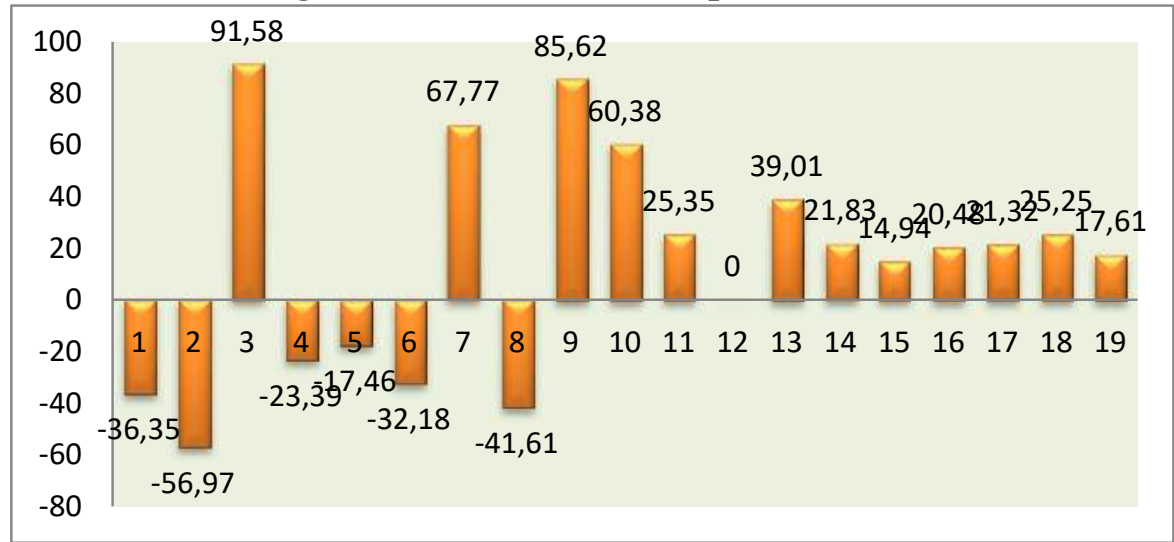

Perkembangan PMDN di Indonesia seperti pada Grafik 3 dimana yang paling rendah yaitu pada tahun 2001 ke 2002 yaitu sebesar -56,97 persen.Secara rata-rata perkembangan PMDN di Indonesia dari tahun 2000-2019 adalah sebesar 15,22 persen pertahunnya. Hasil analisis regresi linear berganda melalui model estimasi dengan pendekatan OLS (Ordinary Least square) dengan tujuan untuk mendapatkan tingkat pengaruh dari masing variabel independet terhadap variabel dependent didapatkan hasil sebagai berikut:

$$
\mathrm{Y}=4,091+1,427 \times 1+0,527 \times 2+2,140 \times 3+e
$$

Dimana:

1. Nilai constanta sebesar 4,091, yang berarti jika variabel $\left(\mathrm{X}_{1}\right)$ pengeluaranpemerintah, $\left(\mathrm{X}_{2}\right)$ angkatan kerja dan $\left(\mathrm{X}_{3}\right)$ PMDN konstan/ tetap/ tidak berubah maka (Y) pertumbuhan ekonomi di Indonesia tetap di angka 4,09 persen

2. Koefisien regresi variabel $X_{1}$ sebesar 1,427 menjelaskan dimana setiap terjadi peningkatan pengeluaran pemerintah sebesar 1 persen maka akan meningkatkan pertumbuhan ekonomi sebesar 1,42 persen dengan asumsi angkatan kerja, dan PMDN relatif atau tidak berubah .

3. Koefisien regresi $\mathrm{X}_{2}$ sebesar 0,52 menunjukan dimana setiap peningkatan angkatan kerja sebesar 1 persen maka pertumbuhan ekonomi meningkat sebesar 0,52 persen dengan asumsi pengeluaran pemerintah dan PMDN dalam keadaan relatif atau tidak berubah .

4. Koefisien regresi variabel PMDN sebesar 2,140 berarti setiap peningkatan PMDN sebesar 1 persen maka akan meningkatkan pertumbuhan ekonomi di Indonesia 
sebesar 2,140 persen dengan asumsi pengeluaran pemerintah, dan angkatan kerja dalam keadaan relatif atau tidak berubah .

Pengujian hipotesis pada penelitian ini menggunakan uji signifikasi statistik secara simultan dan parsial dengan uji satu arah. Hasil pengujian secara simultan dimana nilai $\mathrm{F}$ hitung sebesar 5,716 dengan nilai Sig sebesar 0,008 lebih kecil dari 0,05 $(0,008<0,05)$ maka dapat disimpulkan bahwa secara simultan pengeluaran pemerintah (X1), angkatan kerja (X2) dan PMDN (X3) berpengaruh signifikan terhadap pertumbuhan ekonomi di Indonesia. Sedangkan hasil analisis secara Parsial (Uji t) didapatkan dimana Pengeluaran Pemerintah (X1) Hasil regresi menunjukan nilai $\mathrm{t}$ hitung adalah 3,763 dengan tingkat kepercayaan 95\% diperoleht tabel sebesar 1,734 hasil regresi tersebut menunjukan $\mathrm{t}$ hitung $>\mathrm{t}$ tabel maka dalam hal ini (Ho) ditolak dan (Ha) diterima yang artinya pengeluaran pemerintah di Indonesia berpengaruh signifikan terhadap pertumbuhan ekonomi di ndonesia.

Sedangkan hasil analisis secara Parsial (Uji t) varibel Angkatan Kerja (X2) didapatkan Hasil regresi menunjukan nilai t hitung untuk variabel angkatan kerja adalah sebesar 0,910 dengan tingkat kepercayaan 95\% diperoleh $\mathrm{t}$ tabel sebesar 1,734 hasil regresi menunjukan $\mathrm{t}$ hitung $<\mathrm{t}$ tabel maka dalam hal ini (Ho) diterima dan (Ha) ditolak yang artinya angkatan kerja tidak berpengaruh signifikan terhadap pertumbuhan ekonomi Indonesia.

Selanjutya hasil regresi secara parsial dimana nilai t hitung variabel PMDN sebesar 3,857 dengan tingkat kepercayaan 95\% diperoleh $\mathrm{t}$ tabel sebesar 1,734 hasil regresi menunjukan $\mathrm{t}$ hitung $>\mathrm{t}$ tabel maka dalam hal ini (Ho) ditolak dan (Ha) diterima yang artinya PMDN berpengaruh signifikan terhadap pertumbuhan ekonomi Indonesia. Nilai R Square sebesar 0,533 juga dapat diartikan dimana besarnya pengeluaran pemerintah (X1), angkatan kerja (X2) dan PMDN (X3) mampu mempengaruhi pertumbuhan ekonomi (Y) sebesar 53,3 persen sedangkan sisanya sebesar 46,7 dipengaruhi atau dijelaskan oleh variabel lain yang tidak termasuk dalam penelitian ini.

\section{KESIMPULAN}

Berdasarkan hasil penelitian maka dapat ditarik beberapa kesimpulan sebagai berikut:

1. Perkembangan pengeluaran pemerintah di Indonesia dari tahun 2000-2019 sebesar 20,86 persen pertahunnya, angkatan kerja sebesar 1,82 persen pertahunnya dan Penanaman Modal Dalam Negeri (PMDN) di Indonesia sebesar 15,22 persen pertahunnya. Sedangkan secara rata-rata pertumbuhan ekonomi di Indonesia 
berfluktuasi dengan rata-rata 5,31 persen pertahunnya.

2. Dari hasil regresi didapatkan variabel pengeluaran pemerintah, dan PMDN berpengaruh signifikan terhadap pertumbuhan ekonomi sedangkan angkatan kerja tidak berpengaruh signfikan terhadap pertumbuhan ekonomi.untuk itu diharapkan kepada pemerintah untuk meningkatan kualitas tenaga kerja serta mendorong pengembangan kewirausahaan melaui jalur non formal sehingga tenaga kerja yang ada mempunyai skill dan kemampuan yang baik. Pemerintah juga diharapakan dapat mengalokasikan pengeluaran pemerintah dengan proposional antara belanja langsung dan tidak langsung yang lebih memihak kepentingan publik sehingga mampu memberikan efek yang positif terhadap pertumbuhan ekonomi.

\section{DAFTAR PUSTAKA}

Amiliya, F. (2019). Pengaruh upah minimum dan penyerapan tenaga kerja terhadap tingkat pengangguran terbuka Kabupatn/Kota di Provinsi Banten Tahun 2011-2015 (Doctoral dissertation, UIN SMH BANTEN).

Arsyad, L. (2004). Ekonomi Pembangunan dan Perencanaan Pembangunan. Edisi Keempat. STIE YKPN. Yogyakarta.

Arikunto,S.(2013) Prosedur Penelitian Suatu Pendekatan Praktik. Edisi Revisi. Jakarta: PT. Rineka Cipta

Badan Pusat Statistik, 2021 Publikasi Provinsi Jambi dalam angka yang di akses dalam https://jambi.bps.go.id/

FAUZHIAH, S. (2019). Pengaruh Inflasi, Angkatan Kerja, dan Jumlah Penyerapan Tenaga Kerja terhadap Pengangguran Terbuka di Indonesia Periode Tahun 20142018 (Doctoral dissertation, UIN SMH BANTEN).

Gujarati, D. N. (2003) Ekonometrika Dasar Jakarta : Erlangga.

Khaironi, L. M. (2019). Pengaruh Pengangguran dan Inflasi Terhadap Pertumbuhan Ekonomi di Provinsi Aceh (Doctoral dissertation, UIN Ar-Raniry).

Mainita, M., \& Soleh, A. (2019). ANALISIS INVESTASI ASING LANGSUNG DI INDONESIA. Journal Development, 7(2), 119-131.

Mankiw, G. dkk (2013)“Pengantar Ekonomi Makro. Salemba Empat, Jakarta. 
Marhaeni, A. A. I. N., \& Sirait, N. (2013). Analisis Beberapa Faktor yang Berpengaruh Terhadap Jumlah Pengangguran Kabupaten/Kota di Provinsi Bali. E-Jurnal Ekonomi Pembangunan Universitas Udayana, 2(2), 44430.

Muslim, M. R. (2014). Pengangguran terbuka dan determinannya. Jurnal Ekonomi \& Studi Pembangunan, 15(2), 171-181.

Rizky, R. (2018) “Analisis Hubungan Inflasi dan Pengangguran Di Provinsi Jambi 20132014” Skripsi di publikasi.

Soleh, A. (2017). Masalah ketenagakerjaan dan pengangguran di Indonesia. Jurnal Ilmiah Cano Ekonomos, 6(2), 83-92.

Sugiyono. (2010) Metode Penelitian Bisnis Bandung : CV Alfabeta.

Suparmoko, dkk. (2014) Perekonomian Indonesia Edisi 2 Bogor : In Media. 